\title{
Hubungan Higiene Perorangan Anak dengan Kejadian Kusta Anak di Kabupaten Pasuruan Tahun 2014-2015
}

Nisa Amira, Lilis Sulistyorini

Departemen Kesehatan Lingkungan Universitas Airlangga, Surabaya

Latar belakang. Faktor higiene perorangan yang baik merupakan faktor yang dapat mencegah penularan kusta. Penelitian terdahulu menunjukkan adanya hubungan antara higiene perorangan dengan kejadian kusta. Kasus kusta anak merupakan indikasi masih adanya penularan aktif di masyarakat.

Tujuan. Menganalisis hubungan antara aspek higiene perorangan anak yang meliputi kebersihan badan dan rambut, kebersihan tempat tidur dan kebersihan handuk dengan kejadian kusta anak di Kabupaten Pasuruan tahun 2014-2015.

Metode. Penelitian analitik observasional dengan desain kasus kontrol dilakukan selama bulan Maret-Juni 2016 dengan sampel kasus dan kontrol masing-masing 16 sampel di Kabupaten Pasuruan.

Hasil. Kebersihan badan dan rambut anak yang kurang baik merupakan faktor risiko penularan kusta anak di Kabupaten Pasuruan tahun 2014-2015 (OR: 5,000; IK95\% 1,096-22,820). Kebersihan handuk yang kurang baik merupakan faktor risiko penularan kusta anak tahun 2014-2015 (OR:11,667; IK95\% 1,227-110,953. Kebersihan tempat tidur bukan merupakan faktor risiko penularan kusta anak di Kabupaten Pasuruan tahun 2014-2015. Sari Pediatri 2016;18(3):187-91

Kata kunci: kusta anak, higiene perorangan, faktor risiko

\section{The Relationship between Children's Personal Hygiene and Childhood Leprosy Incidence in Pasuruan Regency 2014-2015}

Nisa Amira, Lilis Sulistyorini

Background. Good personal hygiene is one of factors that could prevent leprosy. Previous studies shown that personal hygiene factors were related to leprosy incidence. Childhood leprosy cases indicate that active leprosy infection still exist in the society.

Objective. This study aims to analyze the relationship between personal hygiene aspects such as children's body and hair cleanliness, children's bedroom cleanliness and children's towel cleanliness with the incidence of childhood leprosy in Pasuruan Regency $2014-2015$. Method. This study was an analytical observational study using case-control design. The study was carried out between March-June 2016, each case and control samples consist of 16 samples situated in Pasuruan Regency.

Results. Inadequate children's body and hair cleanliness was a risk factor to childhood leprosy incidence in Pasuruan Regency 20142015 (OR: 5,000; CI 95\% 1,096-22,820). Inadequate children's towel cleanliness was a risk factor to childhood leprosy incidence in Pasuruan Regency 2014-2015 (OR:11,667; CI 95\% 1,227-110,953). Children's bedroom cleanliness was not a risk factor to childhood leprosy incidence in Pasuruan Regency 2014-2015. Sari Pediatri 2016;18(3):187-91

Keywords: childhood leprosy, personal hygiene, risk factors

Alamat korespondensi: Nisa Amira, Lilis Sulistyorini. Departemen Kesehatan Lingkungan Fakultas Kesehatan Masyarakat Universitas Airlangga. Email: surelamira@gmail. com; lilissulistyorini.unair@gmail.com 
K

usta atau Morbus Hansen merupakan penyakit yang disebabkan oleh Mycobacterium leprae dan menyerang kulit serta Guction kontak langsung dalam kurun waktu yang lama melalui droplet. Masa inkubasi infeksi $M$. leprae adalah 2-5 tahun. ${ }^{1,2}$ Kusta dapat menimbulkan kecacatan apabila penemuan kasus dan pengobatan sangat terlambat.

Kusta diklasifikasikan menjadi dua, yaitu kusta Paucibasiler (PB) dan kusta Multibasiler (MB). Kusta MB lebih mudah menular daripada kusta PB. Ciriciri kusta $\mathrm{MB}$, apabila pada pasien terdapat lebih dari satu tanda $>5$ bercak pada tubuh, penebalan syaraf tepi dan mati rasa, lemah pada otot lebih dari satu syaraf, serta hasil uji laboratorium pada kerokan kulit menunjukkan hasil BTA positif. ${ }^{2}$ Menurut WHO, kusta dapat menyerang semua kelompok umur dan jenis kelamin. ${ }^{3}$ Berdasarkan penelitian terdahulu, sulit untuk menentukan kejadian kusta berdasarkan umur saat timbulnya penyakit, selama ini distribusi menurut umur hanya berdasarkan saat kasus ditemukan sehingga tidak dapat menggambarkan risiko kelompok umur tertentu. ${ }^{2}$

Kusta dapat dicegah melalui perbaikan higiene perorangan. Beberapa hasil penelitian menunjukkan bahwa faktor higiene perorangan yang dapat mempengaruhi penularan kusta adalah kebiasaan tidur bersama, kebiasaan penggunaan handuk dan pakaian bergantian, serta buang air besar di kebun, kebiasaan membersihkan lantai rumah, kebiasaan mandi, kebiasaan mencuci rambut, kebiasaan penggantian alas tidur. $^{4-6}$ Peneliti mengalami keterbatasan memperoleh hasil penelitian sejenis pada kasus anak. Prevalensi kusta secara global terus menurun dari tahun ke tahun sejak penemuan multi drug therapy (MDT). Sebelum pelaksanaan MDT digencarkan sebagai upaya pengendalian kusta, kasus kusta global pada tahun 1980 mencapai angka 5 juta kasus. ${ }^{7}$ Indonesia merupakan salah satu negara dengan kasus baru kusta terbanyak secara global. Pada tahun 2015, Indonesia menempati peringkat ketiga sebagai negara dengan kasus kusta terbanyak setelah India dan Brazil. Provinsi dengan penemuan kasus kusta terbanyak di Indonesia adalah provinsi Jawa Timur. Selaras dengan situasi kusta secara global, penemuan kasus baru kusta di Jawa Timur cenderung mengalami penurunan dari tahun ke tahun. Kasus baru kusta di Jawa Timur tahun 2014 adalah 4116 kasus, pada tahun 2015 mengalami penurunan menjadi 3976 kasus. $^{8}$
Salah satu indikator yang ditetapkan WHO sebagai indikasi adanya penularan kusta secara aktif di suatu wilayah adalah proporsi kasus kusta pada anak. Kusta pada anak merupakan kasus yang terjadi pada anak usia 0-14 tahun. Laporan kusta secara global oleh WHO tahun 2014 menunjukkan bahwa proporsi kasus kusta anak di antara kasus kusta baru 8,8\%. Proporsi kasus kusta anak di Indonesia pada laporan terbaru $11,1 \% .{ }^{9}$ Kasus kusta pada anak perlu perhatian khusus, sebab anak adalah generasi penerus suatu bangsa. Keterlambatan penemuan kasus kusta pada anak dapat menyebabkan kecacatan yang berpengaruh besar terhadap kondisi fisik dan psikis anak yang sedang mengalami masa untuk berinteraksi dengan lingkungan sekitarnya. ${ }^{10,11}$

Persebaran kasus kusta di Jawa Timur berada di wilayah pantai utara dan wilayah Pulau Madura. Salah satu wilayah endemis kusta di Jawa Timur adalah Kabupaten Pasuruan yang merupakan wilayah pantai utara Jawa dan berbatasan dengan Selat Madura. Sama halnya dengan situasi kusta secara global dan nasional, kasus baru kusta di Kabupaten Pasuruan cenderung menurun setiap tahunnya. Meskipun demikian, di antara kasus baru kusta masih ditemukan kasus kusta anak. Hal ini menunjukkan masih adanya penularan aktif di masyarakat. Proporsi kasus kusta anak di Kabupaten Pasuruan adalah 13\%, sedangkan pada tahun 2015 mengalami penurunan menjadi $8 \%$. Kondisi tersebut menunjukkan bahwa target nasional proporsi kasus kusta anak 5\% yang ditetapkan Kemenkes RI masih belum terpenuhi di Kabupaten Pasuruan.

\section{Metode}

Penelitian observasional dengan desain kasus kontrol terhadap anak usia 0-14 tahun yang berdomisili di Kabupaten Pasuruan. Kasus penelitian adalah sebagian kasus kusta pada anak usia 0-14 tahun di Kabupaten Pasuruan yang tercatat sebagai kasus kusta di buku register kusta Dinas Kesehatan Kabupaten Pasuruan tahun 2014-2015. Kontrol adalah kasus anak usia 0-14 tahun yang tinggal dalam satu desa yang sama dengan kasus penelitian.

Teknik pengambilan sampel menggunakan metode simple random sampling. Perbandingan antara besar kasus dan kontrol adalah 1:1. Besar sampel kasus 16 dan kontrol 16, keseluruhan 32 kasus. 
Nisa Amira dkk: Hubungan hygiene perorangan anak dengan kejadian kusta

Tabel 1. Hubungan kebersihan badan dan rambut, tempat tidur, dan handuk

\begin{tabular}{lccccc}
\hline Variabel & Kasus $(\mathrm{n})$ & Kontrol (n) & $\mathrm{p}$ & OR & IK95\% \\
\hline Kebersihan badan dan rambut & & & & & \\
$\quad$ Baik & 6 & 12 & 0,033 & 5,000 & $1,096-22,820$ \\
$\quad$ Kurang baik & 10 & 4 & & & \\
$\quad$ Total & 16 & 16 & & & \\
Kebersihan tempat tidur & & & & & \\
$\quad$ Baik & 4 & 9 & 0,072 & 3,857 & $1,856-17,322$ \\
$\quad$ Kurang baik & 12 & 7 & & & \\
$\quad$ Total & 16 & 16 & & & \\
Kebersihan handuk & & & & & \\
$\quad$ Baik & 1 & 7 & 0,037 & 11,667 & $1,227-110,953$ \\
$\quad$ Kurang baik & 15 & 9 & & & \\
$\quad$ Total & 16 & 16 & & & \\
\hline
\end{tabular}

Responden penelitian adalah orang tua/wali dari anak. Data hasil penelitian diperoleh dengan kunjungan ke rumah responden yang kemudian dilakukan pembacaan kuesioner yang berkaitan dengan higiene perorangan anak kepada responden. Data hasil penelitian dianalisis dengan menggunakan uji statistik chi square Pearson dan Fisher's exact test.

Variabel bebas adalah higiene perorangan anak yang meliputi kebersihan badan dan rambut, kebersihan handuk, dan kebersihan tempat tidur anak. Variabel terikat adalah kejadian kusta anak di Kabupaten Pasuruan tahun 2014-2015. Aspek yang dinilai dari kebersihan badan dan rambut anak adalah frekuensi mandi dengan sabun dalam satu hari, frekuensi mencuci rambut dengan shampoo dalam seminggu, serta kebiasaan anak mandi di perairan terbuka. Kebersihan handuk anak ditinjau dari kebiasaan penggunaan handuk anak yang tidak terpisah dengan anggota keluarga lain, kebiasaan menjemur handuk, dan kebiasaan mencuci handuk.

Kebersihan tempat tidur anak ditinjau dari empat aspek, yaitu penggunaan alas tidur, kebiasaan membersihkan tempat tidur, kebiasaan mengganti dan mencuci alas tidur (seprei) dan kebiasaan menjemur kasur/bantal/guling anak minimal satu bulan sekali.

\section{Hasil}

Berdasarkan Tabel 1 didapatkan hubungan antara kebersihan badan dan rambut dengan kejadian kusta $(\mathrm{p}<0,05)$ dan antara kebersihan handuk dengan kejadian kusta anak di Kabupaten Pasuruan tahun 2014-2015 ( $p>0,05)$. Sementara itu, hasil uji statistik lain menunjukkan tidak terdapat hubungan antara kebersihan tempat tidur anak dengan kejadian kusta $(\mathrm{p}>0,05)$.

\section{Pembahasan}

Berdasarkan analisis bivariat, terdapat hubungan antara kebersihan badan dan rambut dengan kejadian kusta anak di Kabupaten Pasuruan tahun 2014-2015. Nilai rasio $O d d s$ menunjukkan anak yang memiliki kebersihan badan dan rambut yang kurang baik lima kali lebih berisiko tertular kusta daripada anak yang memiliki kebersihan badan dan rambut yang baik. Ketiga aspek yang dinilai, yaitu frekuensi mandi dengan sabun dalam satu hari, frekuensi mencuci rambut dengan shampoo minimal dua kali seminggu, dan riwayat anak mandi di perairan terbuka di wilayah endemis.

Frekuensi mandi dengan sabun dan mencuci rambut dengan shampoo pada seluruh anak responden, baik pada sampel kasus maupun kontrol, tergolong baik. Temuan tersebut selaras dengan penelitian Faturahman ${ }^{6}$ di Cilacap yang melaporkan bahwa tidak terdapat perbedaan frekuensi mandi antara penderita kusta dan bukan kusta. Namun, Rismawati ${ }^{5}$ di RSUD Tugurejo, Semarang, melaporkan bahwa frekuensi mandi dan frekuensi mencuci rambut berhubungan dengan kejadian kusta. Berdasarkan aspek riwayat anak mandi di perairan terbuka di wilayah endemis menunjukkan bahwa sebagian besar anak yang didiagnosis menderita kusta antara tahun 2014-2015 di Kabupaten Pasuruan memiliki riwayat mandi di perairan terbuka. 
Wilayah tempat tinggal responden yang berdekatan dengan lokasi wisata air maupun sungai memungkinkan anak untuk bermain dan mandi di sungai. Penelitian Kerr-Pontes ${ }^{12}$ di Brazil melaporkan bahwa riwayat mandi di perairan terbuka setidaknya selama 10 tahun terakhir di wilayah endemis kusta, dapat meningkatkan risiko tertular kusta; dengan penemuan DNA $M$. leprae di perairan wilayah endemis. ${ }^{13}$ Kebersihan badan dan rambut anak perlu untuk dijaga untuk mencegah penularan kusta, sebab $M$. leprae dapat mencapai permukaan kulit melalui folikel rambut dan kelenjar keringat. ${ }^{14}$

Variabel kebersihan anak ditinjau dari empat aspek, yaitu penggunaan alas tidur, kebiasaan membersihkan tempat tidur setiap hari, kebiasaan mengganti dan mencuci alas tidur (seprei) minimal 2 minggu sekali, dan kebiasaan menjemur kasur/ bantal/guling anak minimal satu bulan sekali. Analisis bivariat menunjukkan bahwa tidak terdapat hubungan antara kebersihan tempat tidur anak dengan kejadian kusta anak di Kabupaten Pasuruan. Kondisi di lapangan menunjukkan kebersihan tempat tidur sampel kasus maupun kontrol tidak berbeda jauh. Hasil penelitian ini berbeda dengan penelitian Kerr-Pontes ${ }^{12}$ dan penelitian Patmawati dan Setiani, ${ }^{15}$ yang melaporkan bahwa kebersihan tempat tidur pada aspek penggantian alas tidur (seprei) secara rutin berhubungan dengan kejadian kusta.

Analisis bivariat kebersihan handuk dengan kejadian kusta menunjukkan adanya hubungan yang bermakna. Nilai rasio Odds anak yang memiliki kebersihan handuk yang kurang baik 11,667 kali lebih berisiko tertular kusta daripada anak yang memiliki kebersihan handuk yang baik. Kebersihan handuk dinilai dari aspek pemisahan handuk anak dengan anggota keluarga lain, kebiasaan menjemur handuk anak setiap hari, dan kebiasaan mencuci handuk minimal dua minggu sekali. Penempatan handuk yang tidak tepat seusai mandi dapat menyebabkan handuk semakin lembab, merupakan kondisi ideal yang memungkinkan $M$. leprae dapat hidup. ${ }^{16,17}$ Pemakaian handuk yang tidak terpisah merupakan salah satu faktor higiene perorangan yang dapat memengaruhi penularan kusta. ${ }^{4,6}$ Kebiasaan menjemur handuk di bawah terik mata hari dapat membunuh mikroorganisme yang tidak dapat bertahan hidup di bawah paparan sinar ultra violet, termasuk M. leprae. ${ }^{17}$

\section{Kesimpulan}

Higiene perorangan anak yang meliputi kebersihan badan dan rambut anak serta kebersihan handuk anak berhubungan dengan kejadian kusta anak di Kabupaten Pasuruan tahun 2014-2015. Kebersihan badan dan rambut anak dan kebersihan handuk anak yang kurang baik dapat meningkatkan risiko penularan kusta. Variabel kebersihan tempat tidur anak menunjukkan tidak ada hubungan terhadap kejadian kusta anak di Kabupaten Pasuruan tahun 2014-2015.

\section{Daftar pustaka}

1. Pusat Data dan Informasi Kementerian Kesehatan RI. Infodatin kusta [online] 2015 [diakses pada 30 May 2016]. Didapat dari: URL:http://www.depkes.go.id/resources/download/ pusdatin/infodatin/infodatin_kusta.pdf.

2. Direktorat Jenderal Pengendalian Penyakit dan Penyehatan Lingkungan Kementerian Kesehatan RI. Pedoman nasional program pengendalian penyakit kusta [online] 2012 [diakses pada 26 Mei 2016]. Didapat dari: URL: http://perpustakaan. depkes.go.id:8180/bitstream//123456789/1791/2/BK2012-406. pdf.

3. World Health Organization. Guide to eliminate leprosy as a public health problem. Leprosy elimination group. Geneva Switzerland: WHO; 2000.

4. Yudied AM. Kajian pengendalian potensial faktor risiko penularan penyakit kusta dan intervensinya di Puskesmas Pragaan Kabupaten Sumenep tahun 2007. Buletin Human Media 2008.

5. Rismawati D. Hubungan antara sanitasi rumah dan personal hygiene dengan kejadian kusta multibasiler. Unnes J Pub Health 2013;2:1-10.

6. Faturahman Y. Faktor lingkungan fisik rumah yang berhubungan dengan kejadian kusta di Kabupaten Cilacap 2010. Prosiding Seminar Nasional Peran Kesehatan Masyarakat dalam Pencapaian MDG's di Indonesia pada 12 April 2011 di Tasikmalaya, Indonesia.

7. World Health Organization. Leprosy [online] 2015 [cited 22 April 2016]. Didapat dari: URL: http://www.who.int/ mediacentrelfactsheets/fs101/en/.

8. Dinas Kesehatan Jawa Timur. Profil kesehatan Jawa Timur 2013. Surabaya: Dinkes Jatim;2013.

9. World Health Organization. Global leprosy update. Weekly Epidemiological Record 2015;96:461-76.

10. Rosvanti A, Dewi DK, Hadimulyono M, Listiawan M. Y. Penderita kusta anak baru sebagai tolok ukur derajat 
endemisitas penyakit kusta. Berkala Ilmu Kesehatan Kulit dan Kelamin 2010;22:91-6.

11. Liangbin Y, Jianping S, Min Z, Guocheng Z. Survey on child leprosy patients and problems resulted from the disease in China. Leprosy Review 2015;86:75-9.

12. Kerr-Pontes LRS, Baretto ML, Evangelista CMN, Rodrigues LC, Heukelbach J, Feldmenter H. Socioeconomic, environmental, and behavioural risk factors for leprosy in NorthEast Brazil: results of case-control study. Int J Epidemiol 2006;35:994-1000.

13. Agusni I, Izumi S, Adriaty D, Iswahjudi. Studi Mycobacterium leprae dari alam lingkungan di daerah endemik kusta (bagian ke I). Maj Kedokt Indonesia 2004;12:491-5.
14. Mansjoer A. Kapita selekta kedokteran. Denpasar: Media Aesculapius; 2000.

15. Patmawati, Setiani NO. Faktor risiko lingkungan dan perilaku penderita kusta di Kabupaten Polewali Mandar. Bul Penelitian Kes 2015;43:207-12.

16. Torvinen E, Meklinm T, Torkklo P, Katila M, Paulin L, Nevalainen, A. Mycobacteria and fungi in moisture-damaged building materials. App Environment Microbiol 2006;72: 6822-4.

17. Turankar RP, Lavania M, Singh M. Dynamics of Mycobacterium leprae transmission in environmental context: deciphering the role of environment as potential reservoir. Infection, Genetics and Evolution 2012;12:121-1. 